\title{
FLOWS OF PERSONS AND GOODS ACROSS THE POLISH SEGMENT OF THE OUTER BOUNDARY OF THE EUROPEAN UNION-RESULTS OF A RESEARCH PROJECT
}

\author{
TOMASZ KOMORNICKI \\ Institute of Geography and Spatial Organization \\ Polish Academy of Sciences \\ Twarda 51/55, 00-818 Warszawa, Poland \\ e-mail: t.komorn@twarda.pan.pl
}

\begin{abstract}
In the paper the results of research project "Flows of persons and goods across the Polish segment of the outer boundary of the European Union" are presented. Primary objective of the project was to determine the influence exerted by the strengthening of the function of the political boundary (which took place after Poland had entered the European Union) on the magnitude and structure of cross-boundary flows, in spatial perspective. The study concerned the flows of persons, vehicles and goods across three segments of the Polish national boundary, constituting, at the same time, the fragments of the boundary of the Union, namely those with Russia (Kaliningrad district), Belarus and Ukraine. Flows were analysed at the border according to the crossing points and the modes of transport (road and railway border crossings).

Key words: Poland, Ukraine, Belarus, outer boundary of the European Union, flows of persons and goods, road and railway border crossing
\end{abstract}

\section{INTRODUCTION}

The research project, entitled "Flows of persons and goods across the Polish segment of the outer boundary of the European Union" was carried out at the Institute of Geography and Spatial Organisation of the Polish Academy of Sciences in the years 2007-2009. Its primary objective was to determine the influence exerted by the strengthening of the function of the political boundary (which took place after Poland had entered the European Union) on the magnitude and structure of crossboundary flows, in spatial perspective. At the time the project was started, the terri- 
tory of Poland was included into the Schengen treaty zone. This implied a particular interest in the problems concerning the outer boundary of this zone from the side of political and economic entities, both domestic and European.

Flows across the Polish segment of the outer boundary of the European Union may be a reflection of the bilateral local transboundary interactions, general bilateral trade and flow of people, as well as transit. The roles of these kinds of flows vary over individual segments of the boundary, and even at the individual border crossings. That is why determination of the structure of traffic may allow for indication of the investment priorities, as perceived from the points of view of three different levels, of both authority and businesses: local-self-governmental, national and European.

The study undertaken had, as well, a concrete general European dimension. Conform to the scenarios of spatial development, elaborated within the ESPON 3.2 Project, in the time horizon of the next 25 years Polish eastern border shall remain the outer boundary of the European Union, also in the "competitive" variant, assuming extension of the Union with Turkey and all the Balkan countries. Irrespective of the substantive assessment of the thus formulated scenarios, this would amount to the continuing interest in the interactions across the studied segment of the boundary from the side of the European research programs.

The study concerned the flows of persons, vehicles and goods across three segments of the Polish national boundary, constituting, at the same time, the fragments of the boundary of the Union, namely those with Russia (Kaliningrad district), Belarus and Ukraine. Flows were analysed at the border according to the crossing points and the modes of transport (road and railway border crossings). For purposes of determination of the magnitude of transit auxiliary analysis was carried out of the flows across other boundaries of Poland (in particular-the Polish-German and Polish-Lithuanian borders). The structure of flows of persons and vehicles was considered from the viewpoint of citizenship of persons crossing the border and (in case of selected border crossings, where field studies were performed) also with respect to their approximate places of residence. The structure of flows of goods in Polish foreign trade was analysed in the breakdown according to the countries of origin (imports) and destination (exports), as well as Polish provinces of origin (exports) and destination (imports). This made possible determination of the magnitudes of internal and external flows according to directions of flows through different segments of the boundary and crossing points.

Analysis of cross-border traffic was carried out on the basis of the data from Border Guards. Cross-border traffic was analysed in dynamics in two time series: (a) long-term for the period 1990-2008; (b) two-year (data summed in monthly periods) for the crucial time interval September 2002-August 2004 (encompassing the dates of introduction of visas for the eastern neighbours of Poland in October 2003 and of the very extension of the Union in May 2004). The analysis of flows of goods in the Polish foreign trade was done based on the data from the Customs Department of the Ministry of Finance. The segments of the Polish boundary with Ukraine, Belarus 
and Russia are currently the only ones, where it is possible to spatially disaggregate flows of goods in the framework of Polish foreign trade (the present paper shows the results from the analysis of trade with eastern neighbours of Poland in the breakdown into counties, while disaggregation associated with directions of transport is the subject of another paper in the volume, authored by Barbara Szejgiec). The study of incoming tourist traffic from the eastern neighbouring countries was carried out using the materials from the Central Statistical Office (GUS), providing the image of spatial distribution of accommodation services, provided to foreigners, in the setting of counties and according to the citizenship of the accommodated tourists. Given the difficulties in carrying out comparisons (various categorisations of the accommodation facilities) only the data for 2007 were used in this study. Field studies concerned the distribution of vehicle traffic from the border crossings. These field studies were carried out by registering the license plates of the vehicles crossing the border at a number of points, selected for this purpose. This method was successfully used in the 1990s at the Polish-German border during the work connected with realisation of the Polish research project "Foundations for development of the western and eastern borderlands of Poland" and the German project "WestOst Axe", carried out by the Institut fuer Laenderkunde in Leipzig (Komornicki and Powęska 1996; Komornicki and Miros 1997), and earlier on in the studies of the spatial ties of the Lublin centre (Warakomska 1987). A detailed description of the results of field studies is presented in a separate paper in this volume, Europe XXI, entitled European Union external and internal borders-interactions and networks.

Conclusions, which are provided at the end of the present paper, account for the results of analyses, being the subject of the two separate papers, contained in this volume (Szejgiec 2010; Wiśniewski, 2010).

\section{ANALYSIS OF CROSS-BORDER TRAFFIC ON THE BASIS OF DATA FROM THE BORDER GUARDS}

\section{CROSS-BORDER TRAFFIC OF PERSONS}

The original cause for the increase of the passenger traffic across the eastern boundaries of Poland after 1989 was constituted by the political and economic transformations, which took place in Central and Eastern Europe. The direct factors, which contributed to the thus dramatic dynamics of this increase, include (Komornicki 1999): (a) ultimate liberalisation of the Polish passport regulations; (b) far-reaching facilitation of passport regulations in the countries of the former Soviet Union; (c) decentralisation and privatisation of car transport and foreign trade; (d) pauperisation of the societies of the former Soviet Union (motivation of trips to Poland with the aim of selling very cheap low quality products, until 1993-94) and of a part of the Polish society (demand for these products); (e) competitiveness of the goods produced by 
some branches of Polish industry on the markets of eastern neighbours, coupled with very pronounced increase of prices of consumption goods in these countries (economic motivation to the conduct of petty import from Poland); (f) high custom tariffs and excise tax on alcoholic beverages, tobacco products and fuels in Poland, motivating to petty smuggling from behind the eastern border. Many of the factors listed had short-lived and unstable character (see Figure 1). Consequently, intensity of cross-border traffic fluctuated. The percentage share of the traffic across the borders with the countries of the former Soviet Union was the highest in the years 1990-91 (in 1991-altogether roughly 22\%), and systematically decreased afterwards (in 1997: 10.8\%). The very first breakdown in the dynamics of increase took place in the years 1992-93 and was associated with the replacement of the mass visits of the sellers (retailers) by the visits of purchasers (partly wholesalers; Komornicki 1995). A real drop in the intensity of traffic occurred then, however, only at the Lithuanian border. There has been anew an increase along the entire border in the middle of the 1990s. The Russian crisis of 1998 brought the breakdown of traffic on the Russian and Belarusian directions, and to a definite degree, also on the Ukrainian one. Traffic across the border with the Kaliningrad district has never returned later on to the level from 1997. Along the Belarusian and Ukrainian borders there has been a revival in the years 1999-2001 of the petty trade, and hence of the traffic. It was, though, short-lived. The end was brought by the limitations originating from the internal customs policies of the two countries, and also due to the general global situation change after September 2001. The respective changes were on each occasion sharper on the Belarusian border than on the Ukrainian one. Traffic across the Polish-Lithuanian border stabilised and has not been displaying more significant changes over the entire period 1993-2003. Introduction of obligatory visas for the citizens of the neighbouring countries, except for Lithuania, in October 2003, brought about an abrupt drop in traffic, clearly visible in monthly statistics. In the case of boundary with Ukraine, and also with the Kaliningrad district of the Russian Federation, the number of persons crossing the border increased again, though, quite soon. The analogous process on the Belarusian border lasted much longer. The very accession of Poland to the European Union in May 2004 did not exert any more a direct influence on the intensity of traffic. An exception was constituted by the Lithuanian segment, which became the internal border of the Union. In 2004 the number of persons crossing this border increased for the first time in ten years.

In the consecutive years the situation along the particular fragments of the borders got significantly differentiated. A hardly predictable dynamics took place at the border with Ukraine. In 2006 this border was crossed in both directions by close to 20 million persons-almost twice the number from the period of the highest bazaar prosperity of the middle of 1990s. A slight increase of the number of persons crossing the border with Belarus was also noted, to the level of roughly 10 million. The year 2007, which had immediately preceded the extension of the Schengen zone, brought, on the other hand, a decrease of traffic across all three segments of the outer bound- 


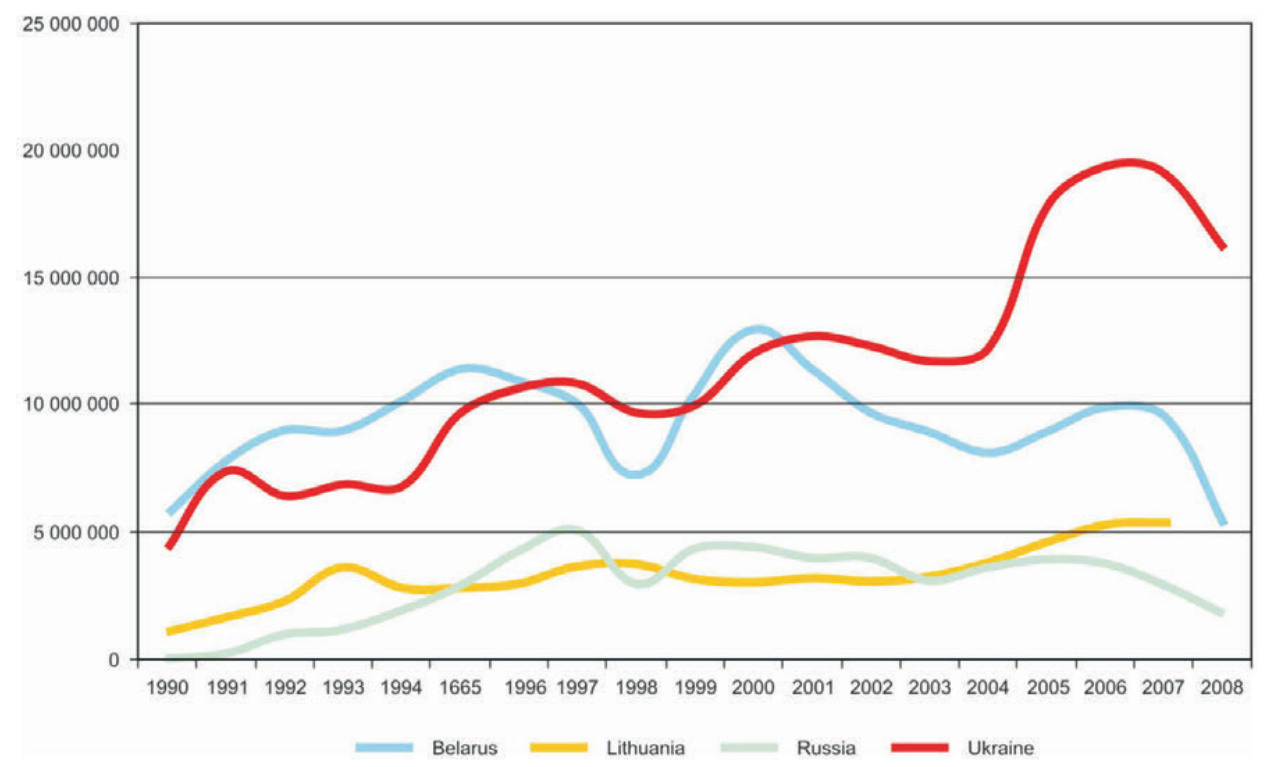

Figure 1. Traffic across the eastern border segments in the years 1990-2008 Source: own elaboration on the basis of data from Border Guards.

ary of the European Union. In the case of the border with Kaliningrad district this was a continuation of the trend started two years before. In 2008, at the borders with Belarus and Ukraine we can speak of true collapse of the bilateral movement of persons. In the case of Belarus the traffic dropped below the level registered in 1990.

There was also a clear differentiation among the particular border segments as to the dynamics of traffic of persons in division into Polish and foreign citizens (Figure 2). In 1990 this structure was mostly balanced (except for Ukraine, where already at that time a perceptible domination of foreigners could be noticed). During the first years of mutual opening up, the societies living on both sides of the border were engaged in a kind of reconnaissance of the economic opportunities (from the Polish side-also of the tourist possibilities - the so-called nostalgic tourism), associated with the new geopolitical situation. This phase lasted longer in the case of Kaliningrad district, with which the border remained closed until as late as 1992. On the remaining segments, already starting with 1991 there was a very quick increase of the share of foreigners (mainly the citizens of the neighbouring countries) in the two-way traffic. On the borders with Russia and Lithuania the number of times the Polish citizens crossed the borders increased, as well, in the former case proportionally, while in the latter case-distinctly slower than for the foreigners. On the borders with Belarus and Ukraine it was as early as in 1991 that a decrease of the number of times Polish citizens crossed the border took place, which persisted until the end of the decade, and in the case of Belarus even until the year 2004. The shifts in the intensity of traffic across the border with Russia were similar for the two categories of persons. Both underwent a decrease after the Russian crisis 
a. Polish-Russian border

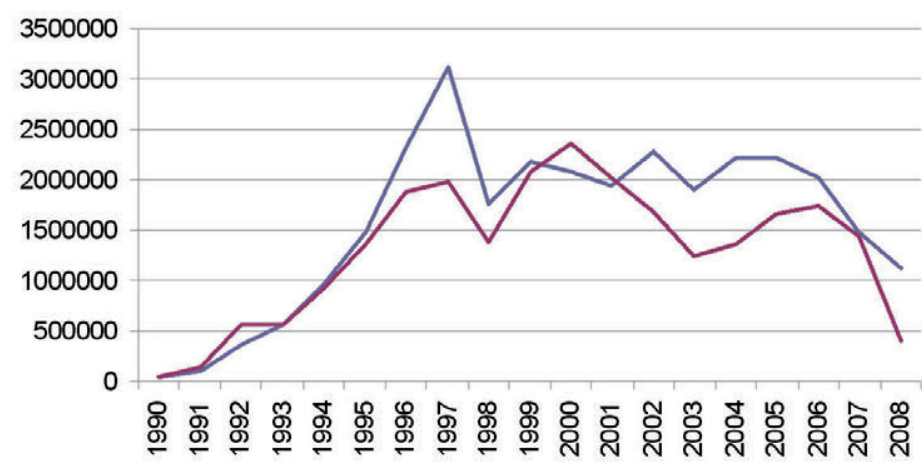

Coles Foreigners

b. Polish-Belarusian border

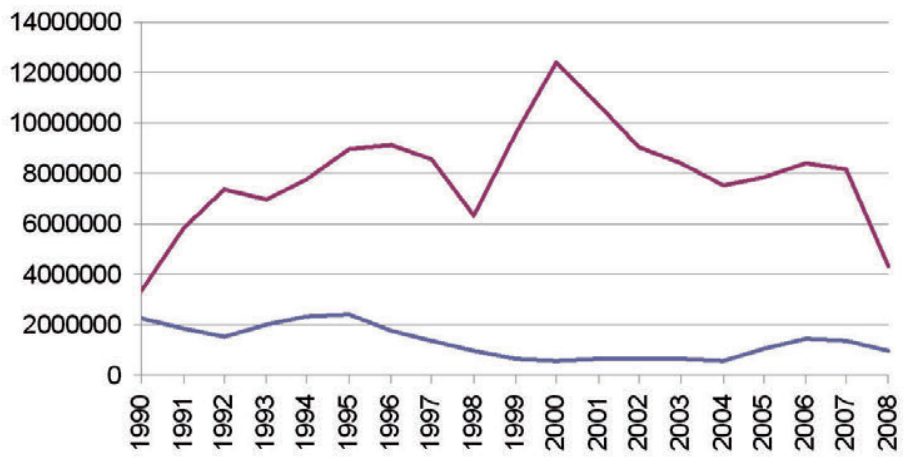

Poles Foreigners

c. Polish-Ukrainian border

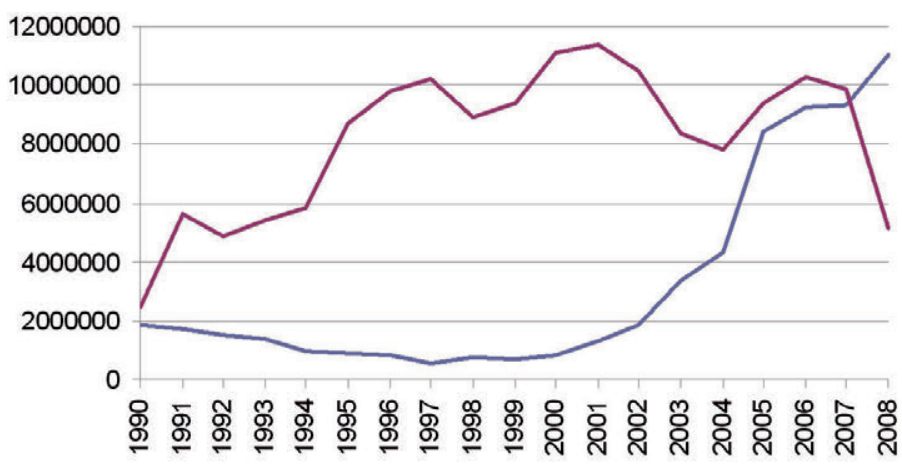

CPoles Foreigners

Figure 2. Structure of traffic across the eastern border segments in 1990-2008

Source: own elaboration on the basis of data from Border Guards. 
of 1998. A balanced structure of traffic persists there until today. After 1994 there was a drop in the trips of Poles across the Lithuanian border. An increase occurred only after the year 2000 .

In the years 1991-2003 the intensity of traffic across the borders with Belarus and Ukraine was entirely determined by the incoming traffic of foreigners. The movement of Poles was marginal. After the visas had been introduced and Poland entered the European Union, this situation changed at the border with Ukraine. There has been a spectacular increase of the number of Poles visiting Ukraine (mainly for purchases of goods charged in Poland with excise tax). Simultaneously, in the PolishBelarusian traffic the clear domination of foreigners persisted. The share of Poles, who crossed this border in 2007, was at mere $13 \%$ (48\% at the Ukrainian border and $50 \%$ at the Russian border). This shows that along the Belarusian segment the trade-and-smuggling activity has not been taken over by Polish citizens (at the Ukrainian border this shift was largely facilitated by the lack of visa obligation for Poles). The breakdown of traffic in 2008, after entering the Schengen zone, entailed very differentiated tendencies in terms of traffic structure. At the Russian border the drop affected both the numbers of Poles and of foreigners, while at the Ukrainian border the drop in the number of Ukrainian citizens was accompanied by a further increase of the number of Poles, crossing this border. Finally, as far as the Belarusian border is concerned, there was fast decrease of the number of foreigners and a slow decrease of the number of Poles crossing this border.

\section{CROSS-BORDER TRAFFIC OF HEAVY LOAD VEHICLES}

The traffic of trucks remained over the entire period considered, 1990-2007, less influenced by the political and micro-economic ("bazaar business cycle") factors than the traffic of persons. Except for the Belarusian segment, it displayed quite systematic upward tendency (Figure 3). In 1990 the major proportion of the crossborder traffic of heavy loads on the eastern direction concentrated on the Belarusian border, and more precisely—at the border crossing in Terespol. The years 1991-1998 were characterised by a fast increase of this traffic over all the segments of the boundary, and a gradual shift of the vehicles towards other border crossing points, first of all the Polish-Lithuanian ones (first to Ogrodniki, and then to Budzisko), followed by the Polish-Ukrainian ones. Year 1998 brought abrupt collapse of the traffic across the Belarusian border and a one-year stop of increase at the borders with Lithuania and Ukraine. Cargo traffic across the border with Russia remained relatively small. After the year 2000 we observe a renewed increase of traffic on all segments. Yet, on the Belarusian border this increase lasted only until 2003, after which stagnation followed and a slight increase in the years 2006-2007 (it was only then that the intensity of traffic from the year 1997 was regained).

The membership of Poland and Lithuania (as well as Latvia and Estonia) in the European Union brought about a spectacular increase of the Polish-Lithuanian traffic in the period 2004-2006. Budzisko became, side by side with Świecko at 
the German border, the Polish border crossing with the most intensive cargo traffic. There has also been a relatively fast increase of traffic across the Ukrainian border, while after 2005 a slight decrease took place in the Polish-Russian traffic. The year 2008 and the membership of Poland in the Schengen zone have not influenced in any significant manner the upward trend of traffic across the Belarusian and Ukrainian borders, and the downward trend in the case of the Russian border.

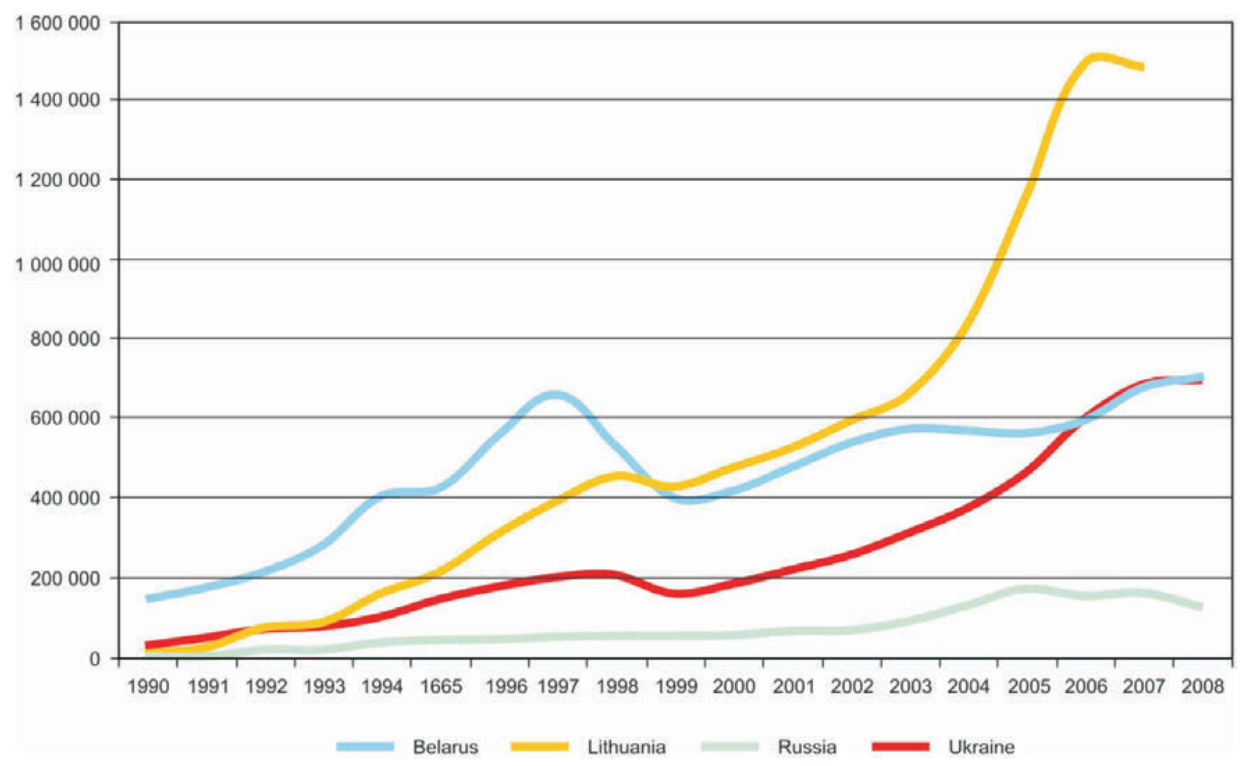

Figure 3. Traffic of heavy loads across the eastern boundary of Poland in 1990-2008 Source: own elaboration on the basis of data from Border Guards.

It is worth emphasising that the entire Polish-Belarusian traffic of trucks $(670,000$ vehicles in 2007) is nowadays smaller than the Polish-Ukrainian one (close to 700,000 vehicles), while in the first half of the 1990s the former was more than three times bigger than the latter. Besides, even the total number of vehicles crossing all the Polish segments of the outer boundary of the European Union (Belarusian, Ukrainian and Russian) is lower than the number of vehicles crossing the inner Union border at one Polish-Lithuanian crossing point in Budzisko (1.5 million vehicles).

The structure of traffic according to the registration of vehicles (Polish-foreign) indicates a steady and usually increasing domination of vehicles registered abroad. At the same time, the impact of Polish accession to the European Union was different for the particular segments of the border. With respect to vehicles with foreign license plates an accelerated increase of traffic took place everywhere. On the other hand, with respect to Polish vehicles, there was a drop on the Russian border, stagnation at the Belarusian border (after the earlier increase), and an increase at the Ukrainian border. 


\section{SPATIAL DISTRIBUTION OF TRADE FLOWS WITH EASTERN NEIGHBOURS}

The distributions of trade flows with the three eastern neighbour countries (Table 1) are quite differentiated in space and time. On the scale of the country the eastern partners play nowadays the most pronounced role in the exports from the provinces of Podlaskie (23\%), Podkarpackie and Mazowieckie. On the other hand, their significance is marginal (below 5\%) in the provinces of Dolnoślaskie, Zachodniopomorskie and Opolskie. The joint share of these three countries in exports from Poland increased from the level of $6 \%$ in 2000 to $8.3 \%$ in 2005 and then close to $9 \%$ in 2007. The biggest increase of this share in the period considered was observed in the provinces of Lubuskie, Świętokrzyskie and Podlaskie, while a characteristic, fast drop occurred in the province of Lubelskie. Yet in the year 2000 this province generated $9 \%$ of exports to Russia, Ukraine and Belarus, while in 2007-only close to $3 \%$. At the same time, there has been an increase of concentration of exports Table 1. Shares of groups of countries $(\%)$ in exports from individual provinces $(2000,2005,2007)$

\begin{tabular}{|c|c|c|c|c|c|c|c|c|c|}
\hline \multirow{3}{*}{ Provinces } & \multicolumn{9}{|c|}{ Groups of countries } \\
\hline & \multicolumn{3}{|c|}{ UE15 } & \multicolumn{3}{|c|}{ UE26 } & \multicolumn{3}{|c|}{ Eastern neighbours* } \\
\hline & 2000 & 2005 & 2007 & 2000 & 2005 & 2007 & 2000 & 2005 & 2007 \\
\hline Dolnośląskie & 80.8 & 75.1 & 71.2 & 90.5 & 88.9 & 88.7 & 1.4 & 2.8 & 3.8 \\
\hline Kujawsko-pomorskie & 75.5 & 67.8 & 69.1 & 84.6 & 77.0 & 81.2 & 7.8 & 10.9 & 9,9 \\
\hline Lubelskie & 54.7 & 56.8 & 58.4 & 63.6 & 68.6 & 73.1 & 22.6 & 15.2 & 14,8 \\
\hline Lubuskie & 86.0 & 75.1 & 74.9 & 92.6 & 84.0 & 83.8 & 2.0 & 8.7 & 10.1 \\
\hline Łódzkie & 70.8 & 61.8 & 59.3 & 81.1 & 76.3 & 76.9 & 9.7 & 13.8 & 13.8 \\
\hline Małopolskie & 58.9 & 60.1 & 59.6 & 77.8 & 81.3 & 81.4 & 7.1 & 8.1 & 7.0 \\
\hline Mazowieckie & 55.3 & 52.1 & 53.9 & 72.8 & 71.5 & 72.6 & 9.7 & 15.3 & 16.1 \\
\hline Opolskie & 81.4 & 72.9 & 66.0 & 93.5 & 87.5 & 86.1 & 2.4 & 4.2 & 4.8 \\
\hline Podkarpackie & 53.0 & 54.6 & 51.2 & 62.8 & 69.6 & 67.0 & 16.0 & 15.1 & 17.2 \\
\hline Podlaskie & 55.4 & 58.3 & 42.3 & 73.1 & 72.0 & 67.1 & 15.7 & 20.1 & 23.0 \\
\hline Pomorskie & 70.3 & 54.7 & 57.5 & 76.5 & 61.3 & 65.6 & 3.6 & 4.5 & 5.2 \\
\hline Śląskie & 75.5 & 71.9 & 69.3 & 88.7 & 86.4 & 86.3 & 2.4 & 2.9 & 5.1 \\
\hline Świętokrzyskie & 70.0 & 61.5 & 58.4 & 78.6 & 75.6 & 79.1 & 6.3 & 10.7 & 11.6 \\
\hline Warmińsko-mazurskie & 68.9 & 71.8 & 66.1 & 76.8 & 81.5 & 79.0 & 8.1 & 7.0 & 8.0 \\
\hline Wielkopolskie & 83.0 & 71.7 & 71.3 & 90.6 & 82.2 & 83.2 & 4.0 & 5.9 & 7.2 \\
\hline Zachodniopomorskie & 70.7 & 74.6 & 73.9 & 74.5 & 77.7 & 78.7 & 1.9 & 3.8 & 4.1 \\
\hline Not specified & 58.7 & 53.4 & 0.0 & 68.7 & 62.0 & 0.0 & 11.1 & 20.1 & 0.0 \\
\hline POLSKA & 70.1 & 64.8 & 64.1 & 81.4 & 78.2 & 79.6 & 6.0 & 8.3 & 8.8 \\
\hline
\end{tabular}

* Russia, Belarus and Ukraine

Source: own elaboration on the basis of materials from the Ministry of Finance, Komornicki (2009). 
in the eastern direction in Mazowieckie, Śląskie, Wielkopolskie and Dolnośląskie. Summing up, it should be stated that although the eastern partners do still play a relatively more important role in the eastern provinces, the biggest outward flows in this direction have moved away from the direct vicinity of the border towards the main exporting areas of central and western Poland.

\section{UKRAINE}

Exports to Ukraine have been increasing fast in the years 2000-2007. The biggest dynamics has been observed in this period in the provinces of Dolnośląskie, Lubuskie and Mazowieckie, the lowest one, characteristically, in the border-adjacent province of Lubelskie. Trade with Ukraine has already in the 1990s been characterised by a specific geographical distribution, referring to two transport-and-development axes: the parallel one, from the border with this neighbour towards Cracow, and
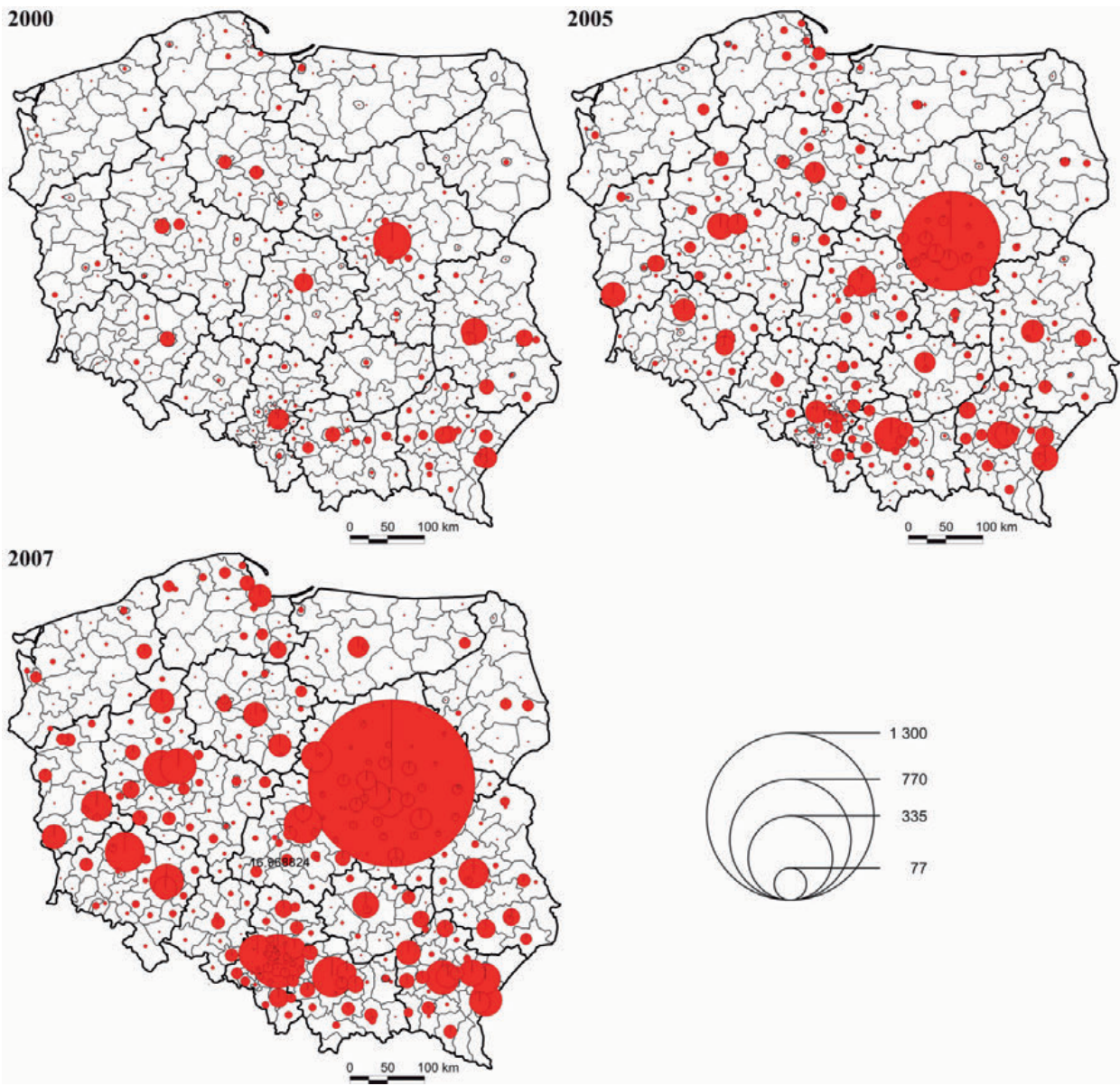

Figure 4. Exports to Ukraine (in million USD)—2000, 2005 and 2007

Source: own elaboration on the basis of materials from the Ministry of Finance, Komornicki (2009). 

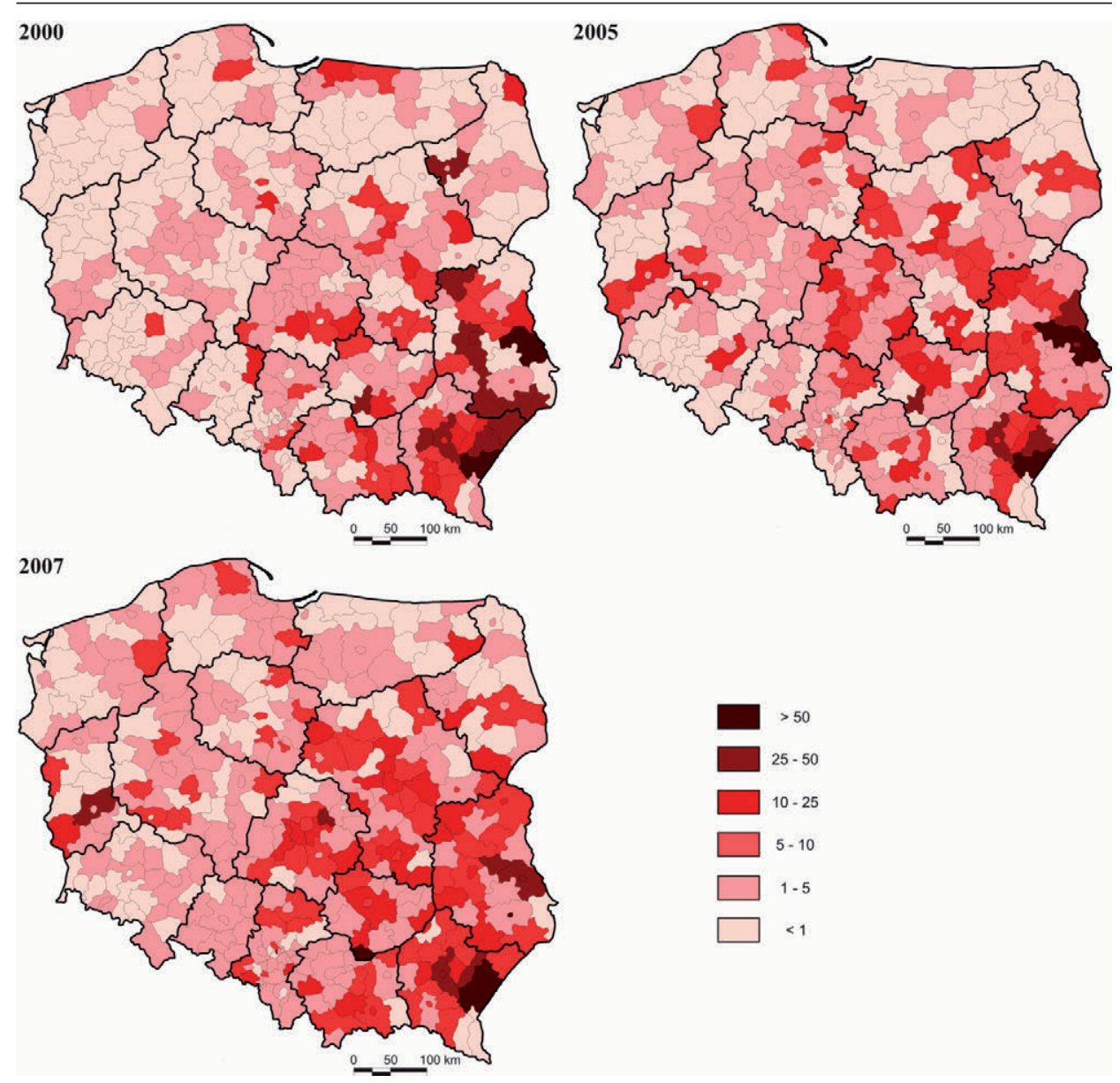

Figure 5. Share of Ukraine in exports (in \%)—2000, 2005 and 2007

Source: Own elaboration on the basis of materials from the Ministry of Finance, Komornicki (2009).

the oblique one, from the border, through Lublin, towards Warsaw. At the same time, there was a significant concentration of trade in the border adjacent regions. In the years 2005 and 2007 (Figure 4) there has been, first, an extension of the length of the two zones, mentioned above, of stronger economic connections (in the directions of, respectively, Wrocław and Gdańsk), and then the spatial setting described got blurred, mainly owing to the faster increase of exports from the province of Wielkopolska. The area, encompassing the units with more than $5 \%$ of share of Ukraine in exports, increased in the western and northern directions (Figure 5). At the same time, the relative significance of trade with the neighbours within the border-adjacent areas of Podkarpackie and Lubelskie provinces decreased. This does not change the fact that it is in these provinces that administrative units are located, from which still more than $80 \%$ of exports are directed to Ukraine (the counties of Przemyśl, Jarosław and the town of Zamość). Among the big 
cities, decidedly the strongest ties with the Ukrainian partners are observed in Lublin (17.5\% of exports), followed by Warsaw (9.5\%) and Lodz (6.1\%). On the other hand, the relative significance of Ukraine is relatively the lowest in the economies of Szczecin and Gdańsk.

\section{BELARUS}

In the years 2000-2007 Belarus maintained-despite definite difficulties in political relations-the level of economic ties with Poland that was proportional to the general increase of Polish exports. This means that the share of Belarus in Polish exports remained stable (around $0.8 \%$ ). The spatial distribution of the administrative units, associated with the Belarusian market, is linked with the course of respective boundary (Figure 6). Deeper in the Polish territory, though, it does not reflect the course of transport axes, as this was the case with exports to Ukraine.
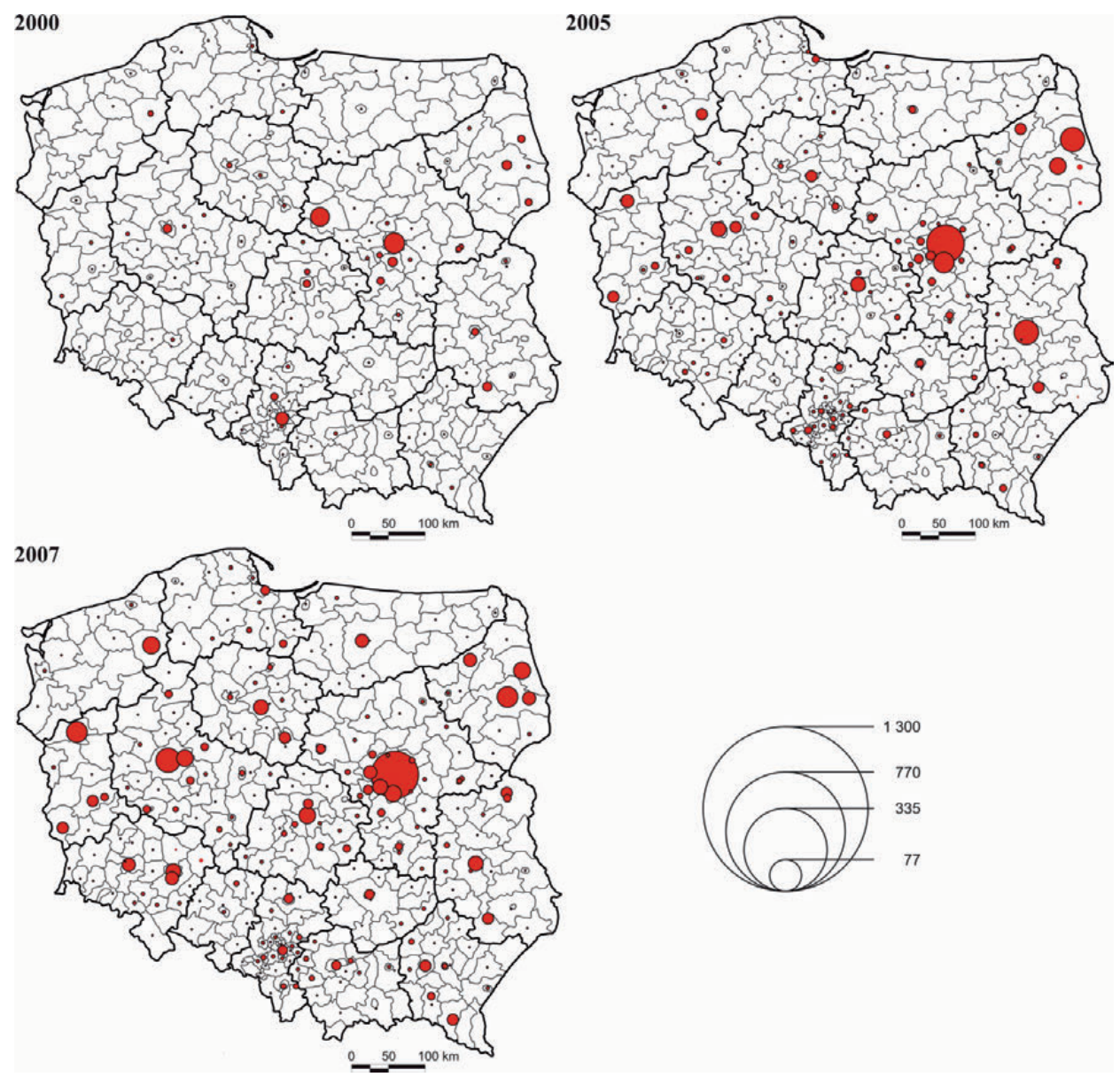

Figure 6. Exports to Belarus (in million USD)—2000, 2005 and 2007

Source: own elaboration on the basis of materials from the Ministry of Finance, Komornicki (2009). 
The changes in the spatial reach of the economic ties with Belarus in the period of study have not been spectacular at all (Figure 7). Even though there has been an increase of exports from the spatial units deeper inside the country (and hence a relative decrease of the role of this export in the border-adjacent areas), yet this applied to only a limited number of counties. The strongest ties with Belarus continued to characterise the counties of the province of Podlaskie (Sokółka: 43\% of exports) and the northern part of the province of Lubelskie. Of larger centres most strongly linked with Belarus were, therefore, in a natural way, Białystok (8.5\% of exports in 2007) and Lublin (close to 5\%). At the level of entire provinces the leading ones in terms of the share of exports going to Belarus are decidedly Podlaskie (close to $7.5 \%$ ) and Lubelskie provinces, while the highest dynamics with this respect is displayed by the provinces of Dolnoślaskie, Lubuskie and Świętokrzyskie.
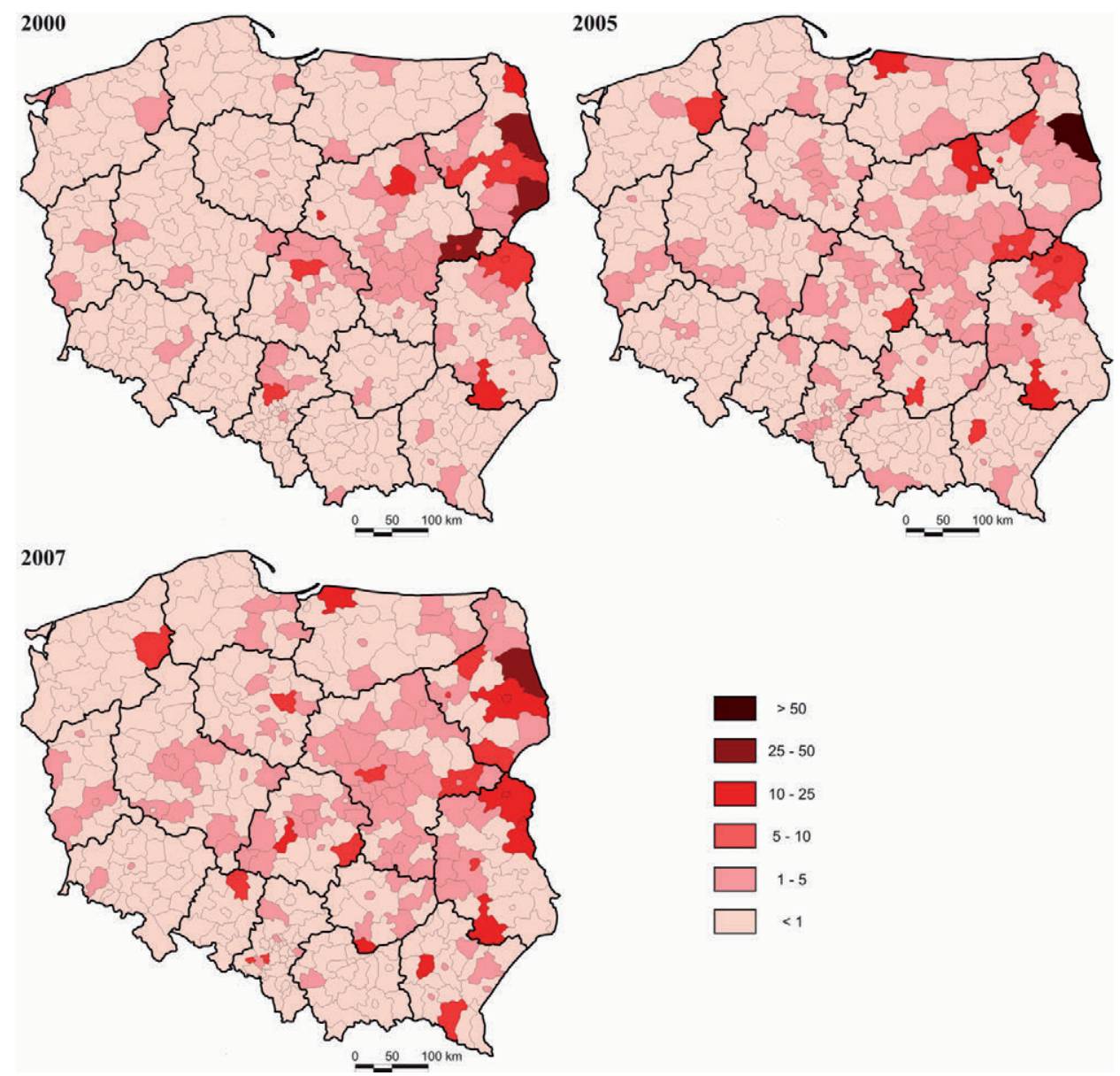

Figure 7. Share of Belarus in exports (in \%)-2000, 2005 and 2007

Source: own elaboration on the basis of materials from the Ministry of Finance, Komornicki (2009). 


\section{RUSSIA}

The role of Russia as the Polish trade partner is based primarily on the import ties (fuels). At the same time, exports, especially in some definite branches, were in the period of study dependent upon the political factors. This was reflected in both the fluctuations of the total export value and in the changes of its territorial distribution in Poland (Figure 8). The provinces, in which exports to Russia concentrate, are Mazowieckie, Podlaskie and Warmińsko-mazurskie, the latter being adjacent to the border with Kaliningrad district. In the years 2000-2007 the highest dynamics of exports in this domain was displayed by Podlaskie. The relative role of Warmińsko-mazurskie has been decreasing. Yet, the highest indicators of dynamics have been observed in the provinces of western Poland and in Świętokrzyskie. Consequently, we can speak of the evening out of the spatial distribution of administrative units, where the significance of the Russian partners in outward trade is relatively
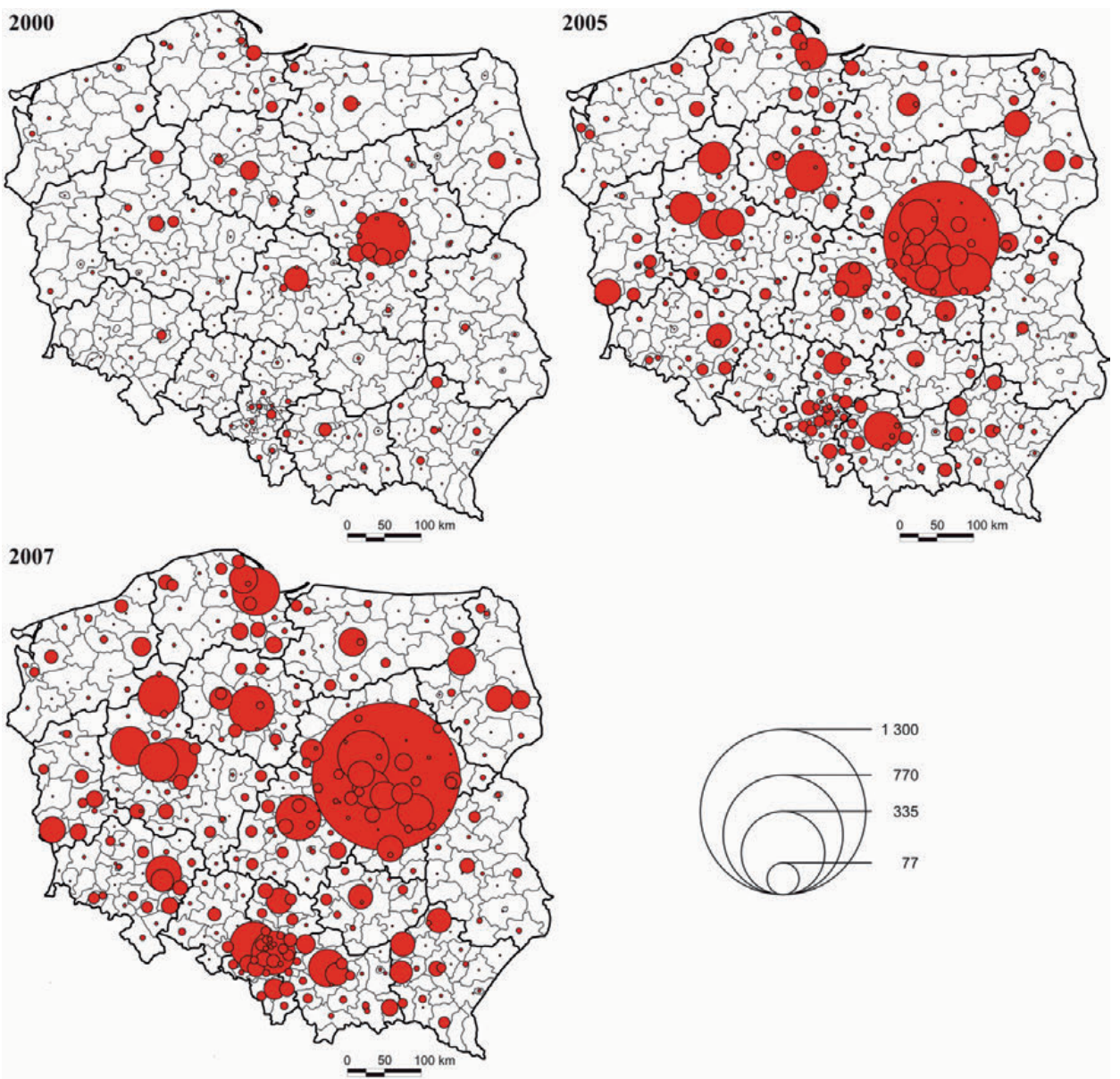

Figure 8. Exports to Russia (in million USD)—2000, 2005 and 2007

Source: own elaboration on the basis of materials from the Ministry of Finance, Komornicki (2009). 
high (Figure 9). This occurred mainly through the inclusion in this trade of the counties from western Poland. On the other hand, the politically conditioned limitations exerted a clearly stronger influence on the local ties in the border-adjacent areas (a spectacular drop of exports from the county of Ostróda-the meat processing company Morliny). Among the large Polish cities the most closely connected, in terms of exports, with Russia are Lodz, Warsaw, Bydgoszcz, Lublin and Gdańsk
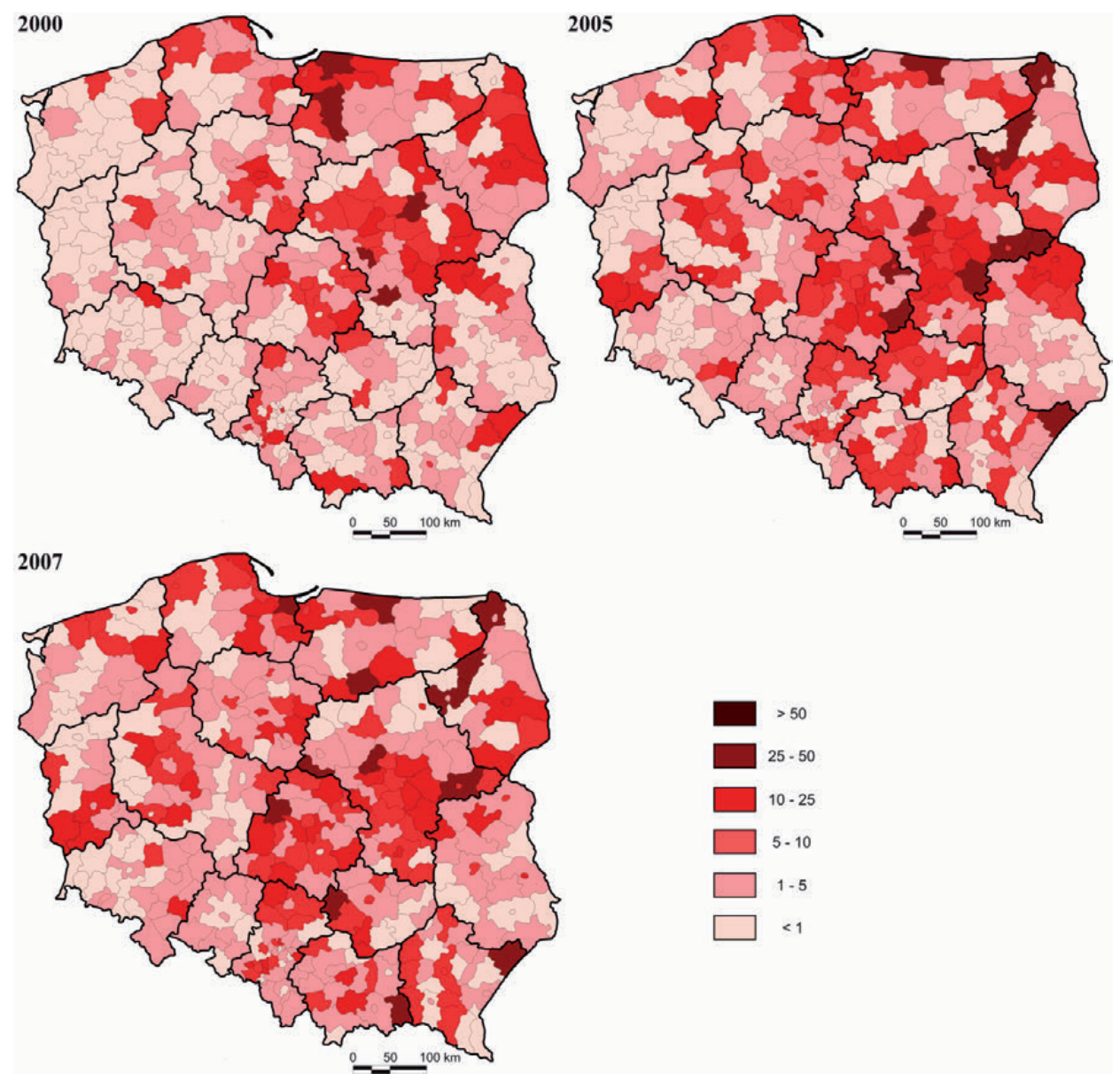

Figure 9. Share of Russia in exports (in \%) -2000, 2005 and 2007

Source: own elaboration on the basis of materials from the Ministry of Finance, Komornicki (2009).

\section{INCOMING TOURIST TRAFFIC FROM THE NEIGHBOURING COUNTRIES}

The study of the incoming tourist flows from the neighbouring countries was carried out on the basis of data from the Central Statistical Office (GUS), concerning overnight stay accommodation provided to foreigners in the setting of counties and 
according to the citizenship of the visitors. These data are, for obvious reasons, charged with a definite error, resulting from the high share of one-day visits (especially within the border-adjacent areas), as well as accommodation provided without any registration by the public statistics. The interpretation of the data must, therefore, be very careful. Notwithstanding these reservations, it can be assumed that the information collected may constitute a significant insight into the assessment of the internal structure of the transboundary interactions. The overnight stays in the accommodation premises can be treated as an indirect measure of the true tourist flows and the official business and institutional contacts (business and official trips). At the same time, contacts associated with petty trade, employment and family relations do most probably not find a reflection in the use of accommodation facilities.

The area of eastern Poland, of highest interest for us, participates to a very limited degree in the entirety of the foreign, incoming, registered tourist traffic, which, on the scale of the country, concentrates in the biggest urban centres (especially in Warsaw and Cracow) and in some regions, attractive for tourists (mainly in Zachodniopomorskie). In the East of Poland, the more important areas of inward tourism are the region of Large Masurian Lakes (in particular, the county of Mragowo) and the provincial centres, including, first of all, Lublin and Białystok. All of these areas feature a relatively high-against the background of entire Poland-share of visitors being the citizens of neighbouring eastern countries.

\section{TOURISTS FROM UKRAINE}

The distribution of overnight accommodation, provided to tourists from Ukraine, indicates, again, the highest concentration of the bilateral interactions in the big-

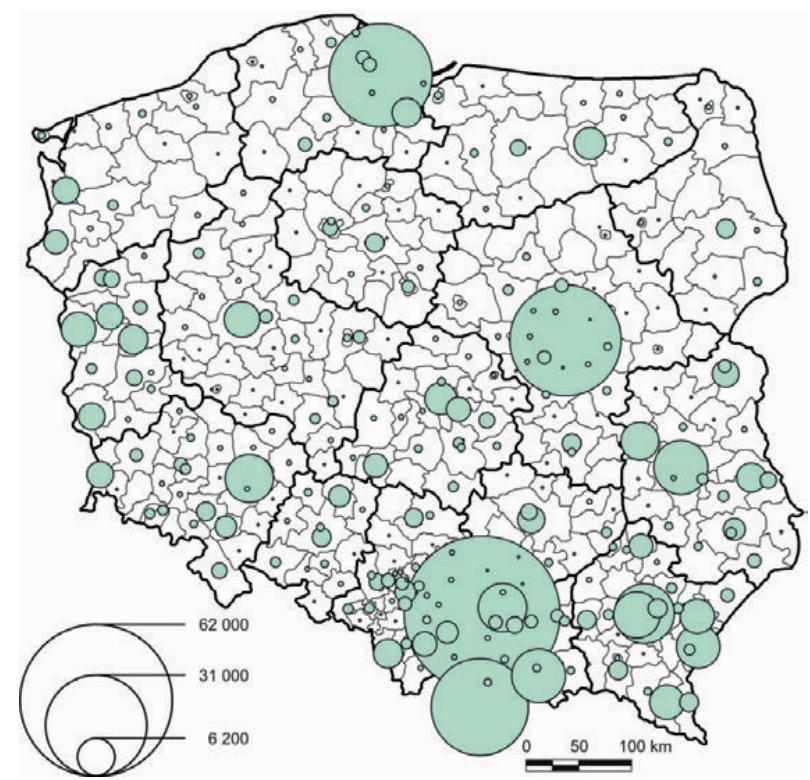

Figure 10. Overnight stays of the citizens of Ukraine in 2007 Source: own elaboration on the basis of data from GUS. 
gest Polish centres (Figure 10), first of all in Warsaw, Cracow and Gdańsk, followed by Wrocław. Besides, the presence of the genuine tourists from Ukraine can be seen in Zakopane, Krynica, in Middle Pomerania, and in the area of Large Masurian Lakes. Within the borderland the highest absolute numbers of overnight stays of the Ukrainian citizens were registered in Rzeszów, Przemyśl, Lublin, and in the counties of Puławy and Jarosław. At the same time, the entire area of the provinces of Podkarpackie and Lubelskie feature very high share of Ukrainians among the foreigners staying their overnight. As mentioned already, though, this is essentially due to the generally low level of development of international tourism on these areas. A relatively higher absolute number and share of overnight stays of the citizens of Ukraine have also been registered on the areas along the German border (especially in the province of Lubuskie), which is most probably the effect of taking advantage of the last opportunities of using cheaper accommodation services during transit trips.

\section{TOURISTS FROM BELARUS}

The numbers of registered overnight stays of the citizens of Belarus in Poland is incomparably lower than for the Ukrainians. Further, there is much less of a concentration in the biggest urban and economic centres (Figure 11). Certain concentration in Warsaw, Cracow and Wrocław can be observed, but all these cities are with this respect well behind Białystok. The use of the genuine tourist services by the Belarusians in Poland is also poorly visible. On the other hand, there is a well perceptible concentration of the accommodation provided to Belarusians in the areas neighbouring the German border (in the county of Stubice the share

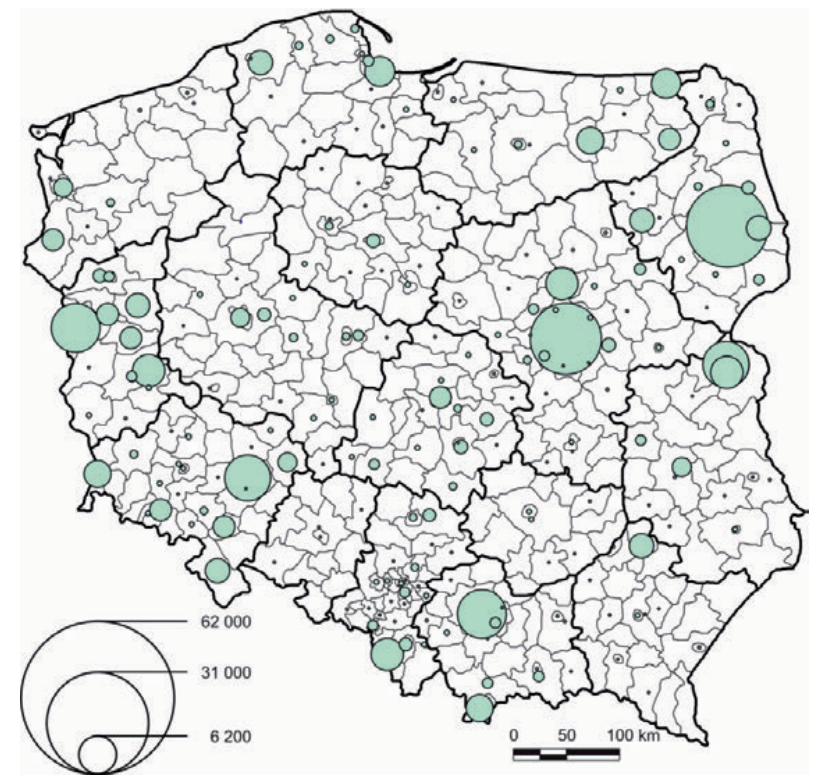

Figure 11. Overnight stays of the citizens of Belarus in 2007 Source: own elaboration on the basis of data from GUS. 
of Belarusians among foreigners staying overnight reaches 30\%). Simultaneously, in the border adjacent area in the province of Podlaskie the concentration of Belarusians among all the registered foreign tourists is by far lower than in the case of Ukrainians. A higher share of overnight stays of these neighbours can, on the other hand, be observed in the northern part of the Lublin region.

\section{TOURISTS FROM RUSSIA}

The registered tourist traffic of the Russians in Poland is characterised by a much higher degree of spatial concentration (see Figure 12) than in the cases of Ukrainians and Belarusians. The spatial pattern is in this case typical for the far off countries, and not for the direct neighbours. An extreme concentration of Russians, staying overnight, is noted in Warsaw, Cracow, the Tri-City, the county of Mragowo (hotel facilities in Mikołajki), Zakopane, as well as borderland counties at the German border (Słubice, Zgorzelec) and at the Czech border (Cieszyn, Kłodzko). There is practically no concentration close to the border with Kaliningrad district, nor to the Belarusian border. Yet, these areas do feature high shares of Russians, spending nights there, in the total numbers of foreigners. Despite this, the highest values of the shares of overnight stays of the citizens of Russia (exceeding 40\%) are noted in the counties of Stubice and Zgorzelec.

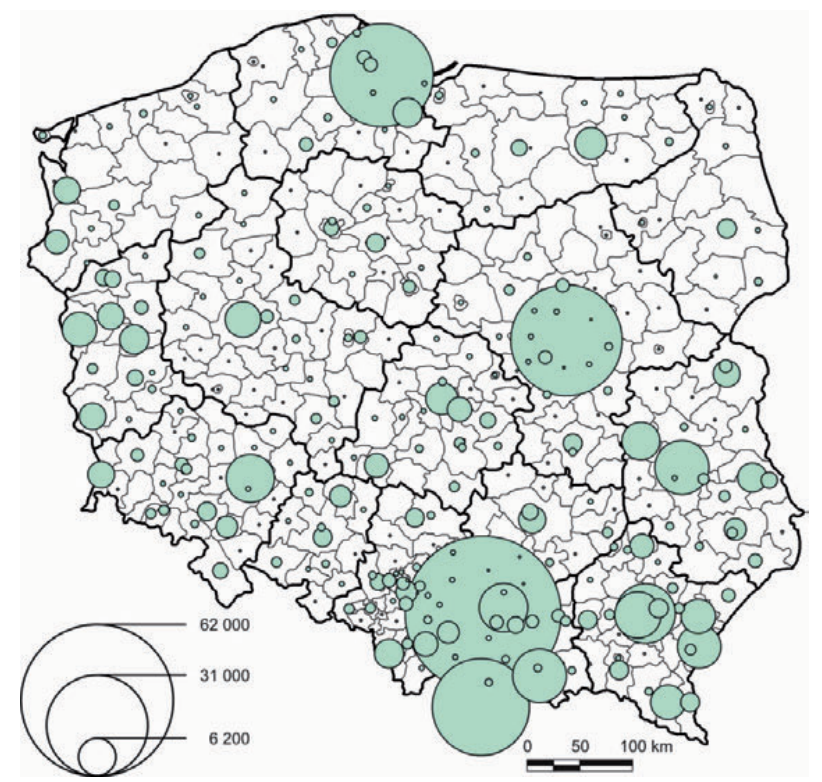

Figure 12. Overnight stays of the citizens of Russia in 2007 Source: own elaboration on the basis of data from GUS. 


\section{CONCLUSIONS}

The renewed strengthening of the function of boundary exerts, first of all, an influence on social relations, with much smaller impact on economic relations. In the latter case the effect of changes in the formal permeability of the border gets translated into the economic activity of the households (petty trade, smuggling, job commuting), while not influencing perceptibly the macroeconomic relations. Inclusion of Polish territory in the Schengen zone turned out to be a more significant event for the magnitude and structure of the cross-border traffic than the very membership in the European Union and the introduction of the visa obligation for the eastern neighbours. Despite the obvious dependencies of political nature, it appears that the intensity of interactions and the magnitude of cross-border flows are much more importantly conditioned by economic factors. The political factor, on the other hand, clearly influences the structure of traffic. It is the reason behind the low share of Poles in the Polish-Belarusian traffic of persons, and also behind the partial shift of the Russian transit towards the boundaries with the Baltic states. The character of the traffic and of the local economic relations remains to an important degree a derivative of the fact that the neighbouring countries do not have fully market based economies. The very first signs of change in this situation appear on the Ukrainian border (symptoms were noted of the evolution towards the kind of cross-border relations that existed at the beginning of the 1990s along the Polish-German border). In this sense the renewed strengthening of the function of the boundary can be perceived as a transitory, and at the same time normalising (economically "purifying") element. The case of the Polish-Ukrainian border demonstrates that in conditions of large differences in the prices of goods (especially those charged with excise tax), petty cross-border trade shall be mainly carried out by the inhabitants of this side of the border, where the transaction costs borne are lower. Introduction of expensive visas for the citizens of Ukraine has not ended their visits in the search for jobs. It had an impact, though, on their participation in the oscillating trade movement. This activity was taken over by the Polish citizens, inhabiting the borderland, who can still travel to Ukraine without visas.

The socio-economic interactions and the border traffic across the eastern border underwent in the years 1990-2007 significant fluctuations. These fluctuations are not conditioned by the degree of development of the respective infrastructure. After 2003-4 the role of border-adjacent location as the stimulator of intensity of relations with the neighbours decreased. The areas, situated along the border, stopped to be the main regions of the official trade with the East. Similarly, the role of bazaar trade decreased (petty trade remained intensive primarily in the zone of smuggling of goods charged with excise tax). At the same time, the eastern borderland of Poland has not become the beneficiary of growth of international tourism. In terms of intensity and structure of the cross-border traffic the situation on the individual eastern segments of the boundary gradually differentiated. The increase of traffic of heavy loads after 2004 (especially across the border with Belarus) lagged disproportionately behind the dynamic increase of bilateral trade. There have been shifts as to the main 
directions of transit traffic. After the year 2000 the route Moscow-Warsaw-Berlin lost the role of the most important East-West transit direction in road transport. The transit transport between the Baltic countries and Western Europe (Via Baltica route) is nowadays several times bigger. It can be supposed that an important part of the Russian transit transport enters the European Union in the Baltic countries and then crosses the border to Poland in Budzisko. Simultaneously, the setting of directions having the biggest significance for Polish foreign trade is much more stable now. This shows that the shifts in cargo traffic affect mainly transit. The result obtained with this respect might be a premise for the concentration of means on this infrastructure (roads, border crossings), which serve mainly Polish businesses. The most important routes from the point of view of Polish economy are in this context the following ones: Warsaw-Minsk, Warsaw-Kiev and Cracow-Lviv, and, with respect to imports, additionally the Metalworking-and-Sulphur Line (LHS).

The transformations having taken place may result in the re-orientation of the currently valid concepts in the domain of the course of transport corridors. High significance of the formal factor in determination of the effectiveness of border procedures on the outer boundary of the European Union shows that potential opening up of new border crossings is currently not a priority from the point of view of improvement of permeability. Moderation with this respect is also implied by the low share of Polish citizens in the bilateral traffic. It might be therefore suggested that an improvement in the permeability of the Polish eastern boundary ought to take place according to the following sequence of the investment—and infrastructure-oriented activities: In passenger traffic:

- enhancement of throughput of the formally existing facilities (like, e.g., minor-border traffic, joint clearance procedures, separation of tourist traffic from petty trade) - bringing back the role of railways on the existing border crossings, including modernisation of the railway lines leading towards the boundary, introduction of new technological solutions at the junction of two railway gauges

- establishment of new road crossing points, with, first of all [a] Polish-Ukrainian ones (Malhowice, Budomierz, Dołhobyczów); [b] tourist crossings (Bieszczady Mts., Vistula Bar).

In cargo traffic:

- solutions in the domain of development of true-to-life transport infrastructure (change of investment priorities in road construction, development of intermodal solutions, especially for transit traffic)

- preservation of the present pattern of border crossings.

\section{REFERENCES}

Komornicki, T. (1995), Powiazania transportowe Polski i Biatorusi-stan aktualny, wykorzystanie, perspektywy; Biuletyn nr 8 programu „Podstawy rozwoju zachodnich i wschodnich obszarów przygranicznych Polski" pt. Problemy polsko-białoruskiej wspótpracy przygranicznej, Warszawa, 53-69. 
Komornicki, T. (1999), Wschodnia strefa aktywności gospodarczej w krajowej i kontynentalnej sieci transportowej (Dynamika układów komunikacyjnych, przejścia graniczne, ruch tranzytowy), in: Horodeński, R. and Rościszewski, M. (eds.) Wschodnia strefa aktywności gospodarczej, Wydawnictwo WSE w Białymstoku, Białystok, 229-252.

Komornicki, T. (2009), Ocena charakteru, struktury i intensywności polskiego eksportu w kontekście celów polityki regionalnej, na poziomie województw w ujęciu; ekspertyza dla Ministerstwa Rozwoju Regionalnego, maszynopis, Warszawa.

Komornicki, T. and Miros, K. (1997), Polsko-niemieckie transgraniczne powiązania społeczno-gospodarcze wzdłuż drogi europejskiej E-40, Przeglad Geograficzny, 69, 3-4, 285-299.

Komornicki, T. and Powęska, H. (1996), Przejścia graniczne: Kostrzyn, Stubice, Świecko, Gubin podstawowe funkcje $i$ strefa oddziaływania na terenie Polski i Niemiec, Zeszyty IGiPZ PAN, 37, 5-40.

Szejgiec, B. (2010), Foreign trade commodity flows across the eastern boundary of Poland, in this volume.

Warakomska, K. (1987), Intensywność ruchu pojazdów mechanicznych na granicy Lublina i powiązania transportowe miasta z innymi województwami Polski, Przeglad Geograficzny, 59, 1-2, 119-134.

Wiśniewski, R. (2010), The intensity and the structure of the cross-border traffic at the eastern boundary of Poland on the basis of a field study, in this volume. 
http://rcin.org.pl 